\title{
MOLECULAR VERSUS HISTOPATHOLOGICAL EXAMINATION OF THE PROSTATE GLAND IN THE ESTIMATION OF POST-MORTEM INTERVAL (AN EXPERIMENTAL STUDY)
}

\author{
Nesrine Abdel Rahman Mahmoud, Asmaa Abdel Rahman Abdel Rahman Hassan, \\ Assem Hassan Abdel Rahim, Suzan Mostafa Mahmoud ${ }^{1}$, and Ola Hassan Nada ${ }^{2}$ \\ Forensic medicine and Toxicology Department ${ }^{1}$, Pathology Department ${ }^{2}$, Faculty of Medicine, \\ Ain -Shams University
}

\begin{abstract}
After death, multiple alterations of biochemical and pathological processes originate resulting in considerable disturbance of the structure and composition of the human body. These changes occur in a sequential manner that may enable estimation of post-mortem interval (PMI). As prostate is the most resistant organ to decomposition, its post mortem histopathological changes as well as pattern of DNA degradation may be useful for PMI determination. This study aimed to investigate the PMI by histopathological examination of the prostate versus its DNA degradation rate in adult male albino rats. Methodology: One hundred and four albino rats were implemented in the study. They were divided into 4 groups (according to the chosen post mortem interval). Group I (early PMI): rats were subdivided into 6 equal subgroups; Group (Ia), (Ib), (Ic), (Id), (Ie) and (If) were examined at PMIs of (zero, 3, 6, 9, 12 and 24 hours, respectively). Group II (intermediate PMI): rats were subdivided into 3 equal subgroups: Group (IIa), (IIb) and (IIc) were examined at PMIs of (2, 4 and 6 days, respectively). Group III (delayed PMI): rats were subdivided into 4 equal subgroups: Group (IIIa), (IIIb), (IIIc) and (IVd) rats were examined at PM interval of (1, 2, 3 and 4 weeks, respectively). Experimental parameters: Prostate was dissected, divided into two portions and left at room temperature. At each scheduled post mortem interval one portion was prepared for light microscopic examination. The other portion was subjected to DNA extraction and agarose gel electrophoresis. Results: light microscopic examination of prostate samples didn't detect any structure abnormality during the first twelve hours post mortem (PM). Twenty-four hours PM significant epithelial disruption, inflammatory cells and fatty degeneration began to appear in the prostatic acini. Two days PM, the prostatic acini showed significant atrophy and necrosis. By six days PM, stromal calcification started to appear. One week to four weeks PM, the prostatic acinar epithelial disruption, atrophic acini, necrosis and stromal calcification became extensive till no more normal glandular or fibromuscular architecture can be detected. The results of extracted glandular DNA showed that DNA resisted the degradation up to twenty-four hours PM. Thereafter, PM degradation patterns progressed to small pieces of low molecular weight DNA less than 400 bp detected at six days PM then to more degraded DNA to reach less than $100 \mathrm{bp}$ at three weeks PM. Four weeks PM, there was complete disappearance of small fragmented molecules. According to the results of this study, it can be concluded that histopathological changes as well as DNA degradation of the prostate were sequential PM processes that are time based. So, they may be used as a predictor of PMI. The slower degeneration of prostate DNA
\end{abstract}


offers a preferable tool for forensic studies at delayed PMI than the histopathological examination of the same organ.

Key words: Prostate -Post mortem interval -DNA

\section{INTRODUCTION}

Estimation of the time of death is an important task of the forensic pathologist achieving examination of the body at the scene of death. Though the real time of death can be hardly estimated based on autopsy findings alone, convenient range of post-mortem interval (PMI) can be concluded by analysis of different changes that take place after death (Chandrakanth et al., 2013).

Following death, a complex series of biochemical and pathological processes are initiated resulting in a considerable alteration of the structure and composition of the human body. As many of these changes occur sequentially, thus the evaluation of the types and degrees of changes may enable estimation of PMI (Ferreira and Cunha, 2013).

Some researchers centered on the microscopic changes rather than macroscopic changes to decrease error (Elias et al., 2004). During the past decades, advances in forensic molecular biology have led to great success in DNA technology for the identification of trace evidence in criminalistics (Madea and Henssge, 2016). So, DNA quantification methods were applied in estimating PMI (Gomaa et al., 2013).

The prostate is considered among the most resistant organs to putrefaction and to post mortem (PM) changes; as it may still be recognizable in a partially skeletalized body for a year PM .This render the prostate a good subject for histopathological as well as DNA analysis for PMI estimation(Saukko and knight ,2016).

\section{AIM OF THE STUDY}

This study aimed to estimate the PMI by histopathological examination of the prostate versus its DNA degradation rate in adult male albino rats.

\section{MATERIAL \& METHODS:}

\section{$>$ Design of the experimental work:}

This current experimental work is intended to assess the PM histopathological changes in the prostate versus its DNA degradation rate in three different intervals; up to 24 hours (from 0 to 24 hours), up to 6 days (from 2 to 6 days) and up to 4 weeks (from 1to 4 weeks) post mortem .

\section{Ethical considerations:}

This study was carried out after the approval of the ethical committee in Ain Shams University (Code number: FWA000017585) taking into considerations the ethical parameters for dealing with experimental animals regarding housing, handling and scarification.

\section{$>$ Animals}

One hundred and four adult male albino rats with an average body weight of 250 to $300 \mathrm{gm}$ were implemented in the present study.

\section{1) Animal housing:}

They were housed as 4 rats/ cage. Stable environmental parameters (temperature, humidity, lighting and sanitation) as well as dietary needs were maintained properly all through the study. The rats were kept in this environment for one week before starting experimentation (Koolhaas, 2010).

\section{2) Animal grouping}

One hundred and four adult albino rats were implemented in the study. 
They were divided into three main groups. Each group was subdivided into a number of subgroups (8 rats each), according to the chosen post mortem interval, as follows:

- Group I (early PMI) (0 hour up to 24 hours PM): 48 rats which were subdivided into 6 equal subgroups :

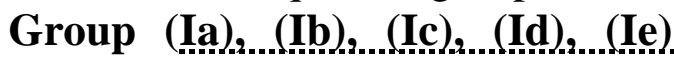
and (If) rats examined at PMIs of (zero, $3,6,9,12$ and 24 hours, respectively). Group (Ia) (zero hour PM) served as control for group I.

- Group II (intermediate PMI) (> 1 day up to 6 days PM): 24 rats were subdivided into 3 equal subgroups :

Group...(IIa),...(IIb)................. rats examined at PM intervals of $(2,4$ and 6 days, respectively). Group (If) (24 hours PM) served as a control for group II.

- Group III (delayed PMI) $(>6$ days up to 4 weeks): 32 rats were subdivided into 4 equal subgroups as follows:

Group..(IIIa), (IIIb), (IIIc) and (IIId) rats examined at PM intervals of (1, 2, 3 and 4 weeks, respectively). Group (IIc) (6 days PM) served as a control for group III.

\section{3) Animal necropsy}

The current study was carried out in April where the climate conditions (temperature and humidity) showed little range of variation from day to day and from day to night. The animals were sacrificed by exsanguinations, achieved by cutting the major blood vessels in the neck to obtain the samples needed for histopathological and gel electrophoresis study (AVMA, 2013). An incision was made in the midline of the animal from the penis to the base of the neck and the prostate was dissected away from the bladder and urethra (Szatkowski et al., 2000). The tissue samples were covered by a wire mesh to prevent scavenger access and subsequently submitted to the intended experimental parameters.

\section{$>$ Experimental parameters}

(1) Histopathological

\section{examination:}

Prostate was dissected and divided into two portions. One portion was collected in a labeled container and left at room temperature. At each scheduled post mortem interval formalin was added to the labeled container, sealed well and stained with Haematoxylin and Eosin (H\&E) to be examined by light microscope. The other portion $(25 \mathrm{mg}$ ) was collected for the DNA analysis.

\section{(2) Agarose gel electrophoresis}

Agarose gel electrophoresis was used in the current study to assess DNA degradation rate (Voytas, 2001). The prostate samples for DNA analysis were collected in a labeled eppendorf tubes and kept at room temperature. At each post mortem interval, the labeled eppendorf tubes were sealed well and stored at $-80^{\circ} \mathrm{C}$ for the DNA analysis to prevent any further nuclease activity.

- DNA extraction: DNA was extracted using QIAGEN extraction Kit DNeasy Blood \& Tissue Kit (50) Cat No. /ID: 69504. Kit contains (50 QIAamp Mini Spin Columns, QIAGEN Protease K, reagents, buffers, $2 \mathrm{ml}$ collection tubes). This kit is designed to purify total DNA from animal tissues and blood.

\section{- Estimation of purity of the DNA samples:}

The purity of each DNA sample was evaluated by ultraviolet spectrophotometry (NanoDrop ${ }^{\circledR}$ ND1000 spectrophotometer); using a comparison of the optical density values of the solution at various wavelengths. A pure DNA sample gives the ratio of the readings at $260 \mathrm{~nm}$ and $280 \mathrm{~nm}$ $\left(\mathrm{A}_{260} / \mathrm{A}_{280}\right)$. However; below 260/280 ratios signifies the presence of a 
contaminating protein (Elkins, 2013(a)). Once the purity of the samples was confirmed, the agarose gel electrophoresis was done.

- Agarose gel electrophoresis was carried out according to the protocol of (Elkins, 2013(b)):

Powdered agarose $(5 \mathrm{~g})$ was added to $50 \mathrm{ml}$ of $1 \%$ TBE (Tris/Borate/EDTA) electrophoresis buffer in $250 \mathrm{ml}$ flask. The agarose was heated in the microwave until it boils, removed from microwave, stained with $5 \mu \mathrm{l}$ of ethidium bromide, poured in the gel platform, and finally gel comb was inserted. After the gel hardened, the comb was removed then $10 \mu \mathrm{l}$ of each DNA sample was added to $1 \mu \mathrm{l}$ of bromophenol blue loading dye and loaded in separate wells on the gel. The voltage was set at $10 \mathrm{~V} / \mathrm{cm}$ gel for 1 hour. After electrophoresis, the agarose gel was photographed to record the presence of amplified products of anticipated sizes. The molecular weight of the DNA fragments was determined by comparison to a 100 bp molecular weight marker.

\section{$>$ Statistical analysis}

Data was checked, revised and analyzed by SPSS statistical package version 19. Excel computer program was used to tabulate the results. Qualitative variables (histopathological and agarose results) were expressed as count and percentages. Chi-square test for distribution was used to show the significant difference between studied groups at $\mathrm{p}<0.05$ (Agresti, 2007)

\section{RESULTS}

Histopathological results: Light microscopic examination of rat's prostate stained with haematoxylin and eosin (H\&E) and application of Chi square $(\chi 2)$ statistical analysis.
- Group I (early PMI)( From zero PMI up to 24 hours):

There was no structure abnormality detected from the time of death (zero hour) till 12 hours PM. The rat's prostate appeared in its classical histological structure; composed of glands and stroma. The glands appeared to be rounded to irregularly branching and lined by two cell layers: an outer low cuboidal layer and an inner layer of tall columnar mucin-secreting epithelium with inward papillary projections. Each gland was surrounded by connective tissue and smooth muscle (fibromuscular stroma) (fig. 1).

Twenty-four hours PM breakdown of the epithelial cells lining the prostatic acini (epithelial disruption) appears in $100 \%$ of the examined animals. At the same time inflammatory cells and fatty degeneration began to invade the smooth muscle fibromuscular stroma of $50 \%$ the examined glands (fig. 2). Chi square analysis detected significant difference for the detected changes (epithelial disruption, fatty degeneration and the presence of inflammatory cells) between subgroup (Ia) (zero hour) and the other group (I) subgroups (table 1).

- Group II (Intermediate PMI)(From > 1 day up to 6 days):

Epithelial disruption of the prostatic acini became significantly noticeable in $100 \%$ of examined samples from (24 hours till 6 days) PM.

Significant atrophy of the prostatic acini was first noticed in $50 \%$ of the examined glands at 2 days and progressed with time to affect $100 \%$ of the samples after 4 days and up till 6 days PM. On application of the Chi square $\left(\chi^{2}\right)$, it gave significant difference when the scheduled post mortem periods were compared to each other or with the ((If) control group) (24 hours PM). 
Inflammatory cells which had already begun to invade the fibromuscular stroma at 24 hours remained to be shown in $50 \%$ of the examined glands till 2 days PM, and then it disappeared completely afterward. Application of the Chi square $(\chi 2)$ gave no significant difference when the scheduled post mortem periods were compared to each other or with the ((If) control group) (24 hours PM).

Fatty degeneration increased by 2 days PM to affect $75 \%$ of rats' prostate, and remained till 4 days PM. Then it progressed to affect $100 \%$ of the examined samples by 6 days PM. Yet, application of the Chi square $(\chi 2)$ gave no significant difference when the scheduled post mortem periods were compared to each other or with their control.

Obvious necrosis of prostatic acini appeared in $50 \%$ of samples at 2 days PM and progressed by time to affect $75 \%$ of samples at 4 days and till 6 days PM. Despite this, application of the Chi square $(\chi 2)$ gave no significant difference when the scheduled post mortem periods were compared to each other or with the ((If) control group) (24 hours PM).

Calcification began to appear for the first time at 6 days PM, affecting only $25 \%$ of examined samples. However, application of the Chi square $\left(\chi^{2}\right)$ gave no significant difference when the scheduled PM periods were compared to each other or with the ((If) control group) (24 hours PM) (fig. 3, 4 and 5) and (table 2).

- Group III (delayed PMI)( From 1 up to 4 weeks PMI):

With the progression of PMI from one to four weeks, the degenerative changes became almost steady but increased in intensity.
Epithelial disruption and the atrophy of the prostatic acini became clearly noticeable in $100 \%$ of examined samples in the PM interval from 1week PM and till 4 weeks PM (Chi square $(\chi 2)$ can't be applied).

Fatty degenerative changes which affected $100 \%$ of the examined glands at 6 days began to decrease by time progression to be seen only in $25 \%$ of samples from 1 week till 4 weeks PM. Application of the Chi square $\left(\chi^{2}\right)$ gave significant difference when the scheduled PM periods were compared to each other or with the ((IIc) control group) (6 days PM).

Necrosis of prostatic acini increased in percentage with the progression of PMI reaching $100 \%$ of the examined animals after one week of death and continued till four weeks. However, application of the Chi square $\left(\chi^{2}\right)$ gave no significant difference when the scheduled PM periods were compared to each other or with the ((IIc) control group) (6 days PM).

Calcification affected only $25 \%$ of examined samples till 4 weeks PM (Chi square $(\chi 2)$ can't be applied). At the end of this period there was complete loss of prostatic architecture (fig. 6, 7 and 8) and (table 3).

$>$ Agarose gel electrophoresis results: analysis of DNA extracted from rats' prostate glands, by agarose gel electrophoresis and application of Chi square $(\chi 2)$ statistical analysis

- Group I (early PMI)( From zero PMI up to 24 hours):

Till 12 hours PM, the extracted DNA of $100 \%$ of the examined samples appeared as a single band near the well which characterizes the whole, nondegraded DNA of $1 \mathrm{~kb}$ size (fig. 9).

Twenty-four hours PM, the extracted DNA of $100 \%$ of the examined glands showed significant 
degradation. This degradation was in the form of a band near the well associated with a homogenous smear down the lane (large pieces of genomic DNA that are partially broken down) (fig.10). These results were evident when the chosen intervals were compared with subgroup ((Ia) (zero hour PM)) and with each other (table 4).

- Group II (intermediate PMI)( From 1 day up to 6 days PM): At 2 days PM the extracted DNA of $100 \%$ of the examined samples appeared as a homogenous smear down the lane (fig. 11).

By 4 days PM, the extracted DNA of $75 \%$ of the examined samples appeared as a homogenous smear, while $25 \%$ of the extracted DNA of the examined animals became more degraded, smeared down the lane to less than 400 bp (fig 12).

By 6 days PM the percent of DNA degraded to less than $400 \mathrm{bp}$ increased to reach $50 \%$ of the examined samples. At the same time the percent of samples showing homogenous smear decreased to only $50 \%$ (fig.13). There was significant statistical difference when the Chi square was applied to the chosen intervals compared to the ((If) control group) (24 hours PM) and with each other (table 5).
- Group III (delayed PMI)(From 1 up to 4 weeks PMI):

At one week PM, the extracted DNA of $100 \%$ of the examined glands appeared degraded to less than $400 \mathrm{bp}$ (fig. 14).

Two weeks PM, fragmentation of DNA became more obvious as the molecular weight of the extracted DNA of $100 \%$ of the examined glands became less than $200 \mathrm{bp}$ (fig. 15).

By three weeks PM, extracted DNA of $100 \%$ of the examined glands became more degraded to reach less than $100 \mathrm{bp}$ molecular weight, in addition to the presence of faint non degraded intact DNA affecting $50 \%$ of examined DNA samples (fig. 16).

At Four weeks PM, the small fragments of degraded DNA migrated completely from the gel leaving intact DNA which appeared in $100 \%$ of the examined samples (fig. 17).

These results were evident as a significant statistical difference when the Chi square was applied to the chosen intervals compared to the ((IIc) control group) (6 days PM) and with each other (table 6). 
Table (1): Chi- $(\chi 2)$ statistical analysis of the histopathological changes of rat's prostate gland of group I (early PMI) in comparison with group (Ia) control group ( zero hour PM) ; eight rats/ each group. Examined by light microscope and stained by H\&E (n=48).

\begin{tabular}{|c|c|c|c|c|c|c|c|c|c|c|c|c|c|c|c|c|c|}
\hline \multirow{4}{*}{$\begin{array}{c}\text { Degenerative changes of } \\
\text { the prostate }\end{array}$} & \multicolumn{17}{|c|}{ Post mortem intervals (PMI) } \\
\hline & \multicolumn{4}{|c|}{24 hours } & \multicolumn{4}{|c|}{2 days } & \multicolumn{4}{|c|}{4 days } & \multicolumn{4}{|c|}{6 days } & \multirow{3}{*}{$\mathrm{p}$} \\
\hline & \multicolumn{2}{|c|}{+ ve } & \multicolumn{2}{|c|}{-ve } & \multicolumn{2}{|c|}{$+\mathrm{ve}$} & \multicolumn{2}{|c|}{-ve } & \multicolumn{2}{|c|}{+ ve } & \multicolumn{2}{|c|}{-ve } & \multicolumn{2}{|c|}{$+\mathrm{ve}$} & \multicolumn{2}{|c|}{-ve } & \\
\hline & $\mathbf{n}$ & $\%$ & $\mathbf{n}$ & $\%$ & $\mathbf{n}$ & $\%$ & $\mathbf{n}$ & $\%$ & $\mathbf{n}$ & $\%$ & $\mathbf{n}$ & $\%$ & $\mathbf{n}$ & $\%$ & $\mathbf{n}$ & $\%$ & \\
\hline Epithelial disruption & 8 & 100 & 0 & $\mathbf{0}$ & 8 & 100 & 0 & $\mathbf{0}$ & 8 & 100 & 0 & $\mathbf{0}$ & 8 & 100 & 0 & $\mathbf{0}$ & - \\
\hline Atrophy of acini & 0 & $\mathbf{0}$ & 8 & 100 & 4 & 50 & 4 & 50 & 8 & 100 & 0 & $\mathbf{0}$ & 8 & 100 & 0 & $\mathbf{0}$ & $P<0.0001(S)$ \\
\hline Inflammatory cells & 4 & 50 & 4 & 50 & 4 & 50 & 4 & 50 & 0 & $\mathbf{0}$ & 8 & 100 & 0 & $\mathbf{0}$ & 8 & 100 & $P<0.013$ (NS) \\
\hline Fatty degeneration & 4 & 50 & 4 & 50 & 6 & 75 & 2 & 25 & 6 & 75 & 2 & 25 & 8 & 100 & 0 & $\mathbf{0}$ & $\mathrm{P}<0.149$ (NS) \\
\hline Necrosis & 0 & $\mathbf{0}$ & 8 & 100 & 4 & 50 & 4 & 50 & 6 & 75 & 2 & 25 & 6 & 75 & 2 & 25 & $\mathrm{P}<0.007$ (NS) \\
\hline Calcification & 0 & $\mathbf{0}$ & 8 & 100 & 0 & $\mathbf{0}$ & 8 & 100 & 0 & $\mathbf{0}$ & 8 & 100 & 2 & 25 & 6 & 75 & $\mathrm{P}<0.093$ (NS) \\
\hline
\end{tabular}

$\mathrm{n}=$ number of rats +ve= number of affected rats $\quad-\mathrm{ve}=$ number of non-affected rats

$\mathrm{S}=$ significant difference

Table (2): Chi- $(\chi 2)$ statistical analysis of some degenerative changes of rat's prostate gland of group II (intermediate PMI) in comparison with group (If) control group (24 hours PM); eight rats/ each group. Examined by light microscope and stained by H\&E.

\begin{tabular}{|c|c|c|c|c|c|c|c|c|c|c|c|c|c|c|c|c|c|c|c|c|c|c|c|c|c|}
\hline \multirow{4}{*}{$\begin{array}{c}\text { Degenerative } \\
\text { changes of the } \\
\text { prostate }\end{array}$} & \multicolumn{24}{|c|}{ Post mortem intervals (PMI) } & \multirow{4}{*}{$\mathbf{P}$} \\
\hline & \multicolumn{4}{|c|}{0 hour } & \multicolumn{4}{|c|}{3 hours } & \multicolumn{4}{|c|}{6 hours } & \multicolumn{4}{|c|}{9 hours } & \multicolumn{4}{|c|}{12 hours } & \multicolumn{4}{|c|}{24 hours } & \\
\hline & \multicolumn{2}{|c|}{$+\mathrm{ve}$} & \multicolumn{2}{|c|}{-ve } & \multicolumn{2}{|c|}{+ ve } & \multicolumn{2}{|c|}{-ve } & \multicolumn{2}{|c|}{$+\mathrm{ve}$} & \multicolumn{2}{|c|}{-ve } & \multicolumn{2}{|c|}{$+\mathrm{ve}$} & \multicolumn{2}{|c|}{-ve } & \multicolumn{2}{|c|}{$+\mathrm{ve}$} & \multicolumn{2}{|c|}{-ve } & \multicolumn{2}{|c|}{$+\mathrm{ve}$} & \multicolumn{2}{|c|}{-ve } & \\
\hline & $\mathbf{n}$ & $\%$ & $\mathbf{n}$ & $\%$ & & $\%$ & $\mathbf{n}$ & $\%$ & $\mathbf{n}$ & $\%$ & $\mathbf{n}$ & $\%$ & & $\%$ & $\mathbf{n}$ & $\%$ & $\mathbf{n}$ & $\%$ & $\mathbf{n}$ & $\%$ & $\mathbf{n}$ & $\%$ & $\mathbf{n}$ & $\%$ & \\
\hline $\begin{array}{l}\text { Epithelial } \\
\text { disruption }\end{array}$ & 0 & $\mathbf{0}$ & 8 & 100 & 0 & $\mathbf{0}$ & 8 & 100 & 0 & 0 & 8 & 100 & 0 & $\mathbf{0}$ & 8 & 100 & 0 & $\mathbf{0}$ & 8 & 100 & 8 & 100 & 0 & $\mathbf{0}$ & $\begin{array}{l}<0.0001 \\
(\mathrm{~S})\end{array}$ \\
\hline Atrophy of acini & 0 & $\mathbf{0}$ & 8 & 100 & 0 & $\mathbf{0}$ & 8 & 100 & 0 & 0 & 8 & 100 & 0 & $\mathbf{0}$ & 8 & 100 & 0 & $\mathbf{0}$ & 8 & 100 & 0 & $\mathbf{0}$ & 8 & 100 & - \\
\hline $\begin{array}{c}\text { Inflammatory } \\
\text { cells }\end{array}$ & 0 & $\mathbf{0}$ & 8 & 100 & 0 & $\mathbf{0}$ & 8 & 100 & 0 & 0 & 8 & 100 & 0 & $\mathbf{0}$ & 8 & 100 & 0 & $\mathbf{0}$ & 8 & 100 & 4 & 50 & 4 & 50 & $\begin{array}{c}\mathrm{P}<0.0006 \\
(\mathrm{~S})\end{array}$ \\
\hline $\begin{array}{c}\text { Fatty } \\
\text { degeneration }\end{array}$ & 0 & $\mathbf{0}$ & 8 & 100 & 0 & $\mathbf{0}$ & 8 & 100 & 0 & 0 & 8 & 100 & 0 & $\mathbf{0}$ & 8 & 100 & 0 & $\mathbf{0}$ & 8 & 100 & 4 & 50 & 4 & 50 & $\begin{array}{c}\mathrm{P}<0.0006 \\
(\mathrm{~S})\end{array}$ \\
\hline Necrosis & 0 & $\mathbf{0}$ & 8 & 100 & 0 & $\mathbf{0}$ & 8 & 100 & 0 & 0 & 8 & 100 & 0 & $\mathbf{0}$ & 8 & 100 & 0 & $\mathbf{0}$ & 8 & 100 & 0 & $\mathbf{0}$ & 8 & 100 & - \\
\hline Calcification & 0 & $\mathbf{0}$ & 8 & 100 & 0 & $\mathbf{0}$ & 8 & 100 & 0 & 0 & 8 & 100 & 0 & $\mathbf{0}$ & 8 & 100 & 0 & $\mathbf{0}$ & 8 & 100 & 0 & $\mathbf{0}$ & 8 & 100 & - \\
\hline
\end{tabular}

Egypt J. Forensic Sci. Appli. Toxicol

Vol 18 (1), march 2018 
Table (3): Chi- $(\chi 2)$ statistical analysis of some degenerative changes of rat's prostate gland of group III (delayed PMI) in comparison with group (IIc) control group (6 days PM); eight rats/each group. Examined by light microscope and stained by H\&E.

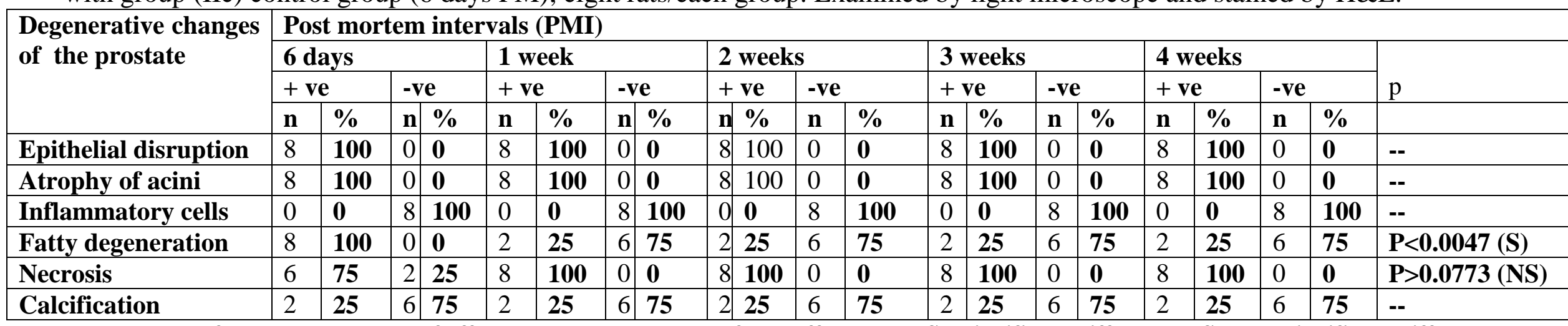

$\mathrm{n}=$ number of rats $+\mathrm{ve}=$ number of affected rats $-\mathrm{ve}=$ number of non-affected rats $\mathrm{S}=$ significant difference NS $=$ non-significant difference

Table (4): Chi- $(\chi 2)$ statistical analysis of DNA pattern of DNA extracts from rats' prostate gland of group I ( early PMI) in comparison with group (Ia) control group (zero hour PM) ; eight rats/ each group. Assessed by agarose gel electrophoresis

\begin{tabular}{|c|c|c|c|c|c|c|c|c|c|c|c|c|c|c|c|c|c|c|c|c|c|c|c|c|c|}
\hline \multirow{4}{*}{$\begin{array}{l}\text { Pattern of } \\
\text { extracted } \\
\text { DNA }\end{array}$} & \multicolumn{24}{|c|}{ Post mortem intervals (PMI) } & \multirow[t]{4}{*}{$\mathrm{P}$} \\
\hline & \multicolumn{4}{|c|}{ O hour } & \multicolumn{4}{|c|}{3 hours } & \multicolumn{4}{|c|}{6 hours } & \multicolumn{4}{|c|}{9 hours } & \multicolumn{4}{|c|}{12 hours } & \multicolumn{4}{|c|}{24 hours } & \\
\hline & \multicolumn{2}{|c|}{$+\mathrm{ve}$} & \multicolumn{2}{|c|}{-ve } & \multicolumn{2}{|c|}{ +ve } & \multicolumn{2}{|c|}{-ve } & \multicolumn{2}{|c|}{$+\mathrm{ve}$} & \multicolumn{2}{|c|}{-ve } & \multicolumn{2}{|c|}{$+\mathrm{ve}$} & \multicolumn{2}{|c|}{-ve } & \multicolumn{2}{|c|}{+ ve } & \multicolumn{2}{|c|}{-ve } & \multicolumn{2}{|c|}{ +ve } & \multicolumn{2}{|c|}{-ve } & \\
\hline & $\mathbf{n}$ & $\%$ & $\mathbf{n}$ & $\%$ & $\mathbf{n}$ & $\%$ & $\mathbf{n}$ & $\%$ & $\mathbf{n}$ & $\%$ & $\mathbf{n}$ & $\%$ & $\mathbf{n}$ & $\%$ & $\mathbf{n}$ & $\%$ & $\mathbf{n}$ & $\%$ & $\mathbf{n}$ & $\%$ & $\mathbf{n}$ & $\%$ & $\mathbf{n}$ & $\%$ & \\
\hline $\begin{array}{l}\text { Single band } \\
\text { near the well }\end{array}$ & 8 & 100 & 0 & $\mathbf{0}$ & 8 & 100 & 0 & $\mathbf{0}$ & 8 & 100 & 0 & $\mathbf{0}$ & 8 & 100 & 0 & $\mathbf{0}$ & 8 & 100 & 0 & $\mathbf{0}$ & 8 & 100 & 0 & $\mathbf{0}$ & - \\
\hline $\begin{array}{l}\text { Homogenous } \\
\text { smear }\end{array}$ & 0 & $\mathbf{0}$ & 8 & 100 & 0 & $\mathbf{0}$ & 8 & 100 & 0 & $\mathbf{0}$ & 8 & 100 & 0 & $\mathbf{0}$ & 8 & 100 & 0 & $\mathbf{0}$ & 8 & 100 & 8 & 100 & 0 & $\mathbf{0}$ & $\mathrm{P}<0.0001(\mathrm{~S})$ \\
\hline DNA laddering & 0 & $\mathbf{0}$ & 8 & 100 & 0 & $\mathbf{0}$ & 8 & 100 & 0 & $\mathbf{0}$ & 8 & 100 & 0 & $\mathbf{0}$ & 8 & 100 & 0 & $\mathbf{0}$ & 8 & 100 & 0 & $\mathbf{0}$ & 8 & 100 & - \\
\hline $\begin{array}{l}\text { Smear in track } \\
<400 \mathrm{bp}\end{array}$ & 0 & $\mathbf{0}$ & 8 & 100 & 0 & $\mathbf{0}$ & 8 & 100 & 0 & 0 & 8 & 100 & 0 & $\mathbf{0}$ & 8 & 100 & 0 & 0 & 8 & 100 & 0 & $\mathbf{0}$ & 8 & 100 & - \\
\hline Smear <200 bp & 0 & $\mathbf{0}$ & 8 & 100 & 0 & $\mathbf{0}$ & 8 & 100 & 0 & $\mathbf{0}$ & 8 & 100 & 0 & $\mathbf{0}$ & 8 & 100 & 0 & $\mathbf{0}$ & 8 & 100 & 0 & $\mathbf{0}$ & 8 & 100 & - \\
\hline Smear <100 bp & 0 & $\mathbf{0}$ & 8 & 100 & 0 & $\mathbf{0}$ & 8 & 100 & 0 & $\mathbf{0}$ & 8 & 100 & 0 & $\mathbf{0}$ & 8 & 100 & 0 & $\mathbf{0}$ & 8 & 100 & 0 & $\mathbf{0}$ & 8 & 100 & - \\
\hline
\end{tabular}


Table (5): Chi- $(\chi 2)$ statistical analysis of the observed DNA pattern of DNA extracts from rats' prostate gland of group II (intermediate PMI) in comparison with group (If) control group (24 hours PM); eight rats/ each group. Assessed by agarose gel electrophoresis.

\begin{tabular}{|c|c|c|c|c|c|c|c|c|c|c|c|c|c|c|c|c|c|}
\hline \multirow{4}{*}{$\begin{array}{l}\text { Pattern of extracted } \\
\text { DNA }\end{array}$} & \multicolumn{17}{|c|}{ Post mortem intervals (PMI) } \\
\hline & \multicolumn{4}{|c|}{24 hours } & \multicolumn{4}{|c|}{2 days } & \multicolumn{4}{|c|}{4 days } & \multicolumn{4}{|c|}{6 days } & \multirow{3}{*}{$\begin{array}{l}\chi^{2} \\
p\end{array}$} \\
\hline & \multicolumn{2}{|c|}{$+\mathrm{ve}$} & \multicolumn{2}{|c|}{-ve } & \multicolumn{2}{|c|}{$+\mathrm{ve}$} & \multicolumn{2}{|c|}{-ve } & \multicolumn{2}{|c|}{+ ve } & \multicolumn{2}{|c|}{-ve } & \multicolumn{2}{|c|}{$+\mathrm{ve}$} & \multicolumn{2}{|c|}{-ve } & \\
\hline & $\mathbf{n}$ & $\%$ & $\mathbf{n}$ & $\%$ & $\mathbf{n}$ & $\%$ & $\mathbf{n}$ & $\%$ & $\mathbf{n}$ & $\%$ & $\mathbf{n}$ & $\%$ & $\mathbf{n}$ & $\%$ & $\mathbf{n}$ & $\%$ & \\
\hline Single band near the well & 8 & 100 & 0 & 0 & 0 & $\mathbf{0}$ & 8 & 100 & 0 & $\mathbf{0}$ & 8 & 100 & 0 & $\mathbf{0}$ & 8 & 100 & $\mathrm{P}<0.0001(\mathrm{~S})$ \\
\hline Homogenous smear & 8 & 100 & 0 & 0 & 8 & 100 & 0 & 0 & 6 & 75 & 2 & 25 & 4 & 50 & 4 & $\mathbf{5 0}$ & $P=0.0290(S)$ \\
\hline DNA laddering & 0 & $\mathbf{0}$ & 8 & 100 & 0 & $\mathbf{0}$ & 8 & 100 & 0 & $\mathbf{0}$ & 8 & 100 & 0 & $\mathbf{0}$ & 8 & 100 & - \\
\hline Smear in track $<400 \mathrm{bp}$ & 0 & $\mathbf{0}$ & 8 & 100 & 0 & $\mathbf{0}$ & 8 & 100 & 2 & 25 & 6 & 25 & 4 & 50 & 4 & 50 & $P=0.0290(S)$ \\
\hline Smear in track <200 bp & 0 & $\mathbf{0}$ & 8 & 100 & 0 & $\mathbf{0}$ & 8 & 100 & 0 & $\mathbf{0}$ & 8 & 100 & 0 & $\mathbf{0}$ & 8 & 100 & - \\
\hline Smear in track $<100$ bp & 0 & $\mathbf{0}$ & 8 & 100 & 0 & $\mathbf{0}$ & 8 & 100 & 0 & $\mathbf{0}$ & 8 & 100 & 0 & $\mathbf{0}$ & 8 & 100 & - \\
\hline
\end{tabular}

$\mathrm{n}=$ number of rats $\quad+\mathrm{ve}=$ number of rats in which the pattern appears appear $\quad b p=$ base pair $-v e=$ number of rats in which the pattern doesn't $\mathrm{S}=$ significant difference

Table (6): Chi- $(\chi 2)$ statistical analysis of the observed DNA pattern of DNA extracts from rats' prostate gland of group III (delayed PM) in comparison with group (IIc) control group (6 days PM); eight rats/each group. Assessed by agarose gel electrophoresis)

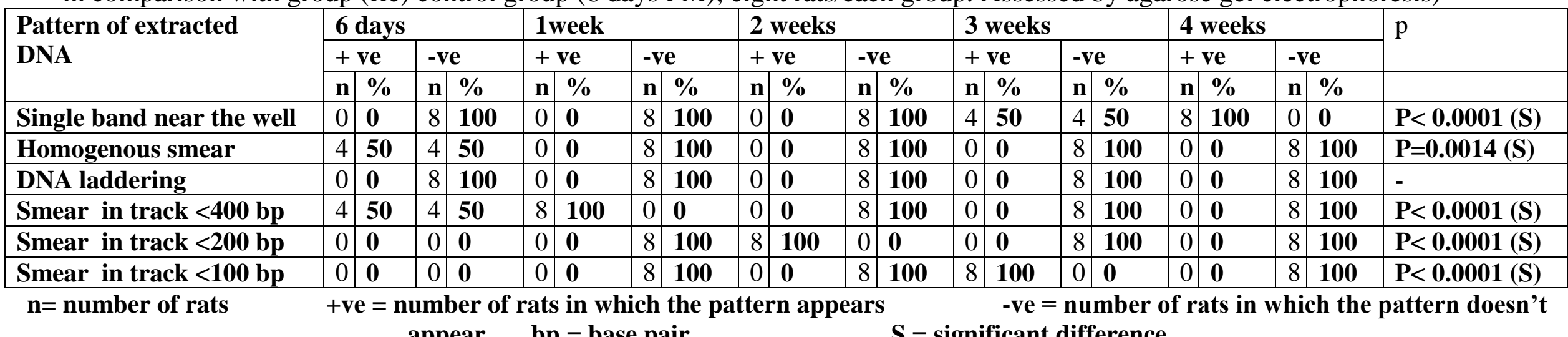
appear $\quad b p=$ base pair $\quad S$ significant difference 

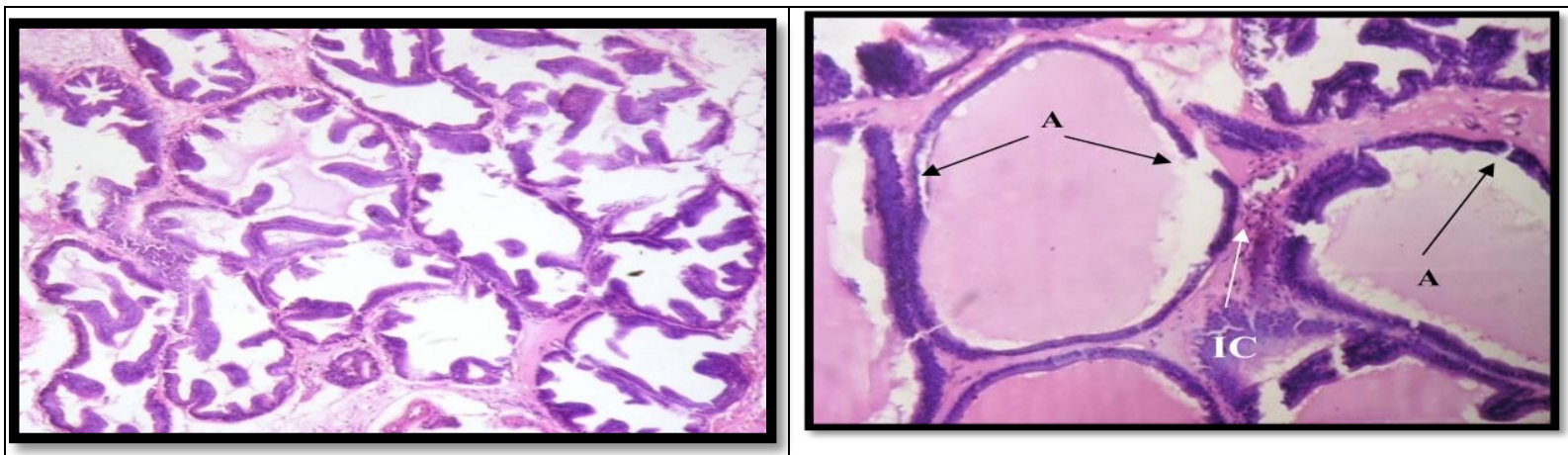

Figure (1): Photomicrograph of rat's prostate stained with (H\&E) shows classical acini and stroma examined at 0 hour PM (control). This normal architecture is retained up to 12 hours PM (light Mic.Mag.X100).

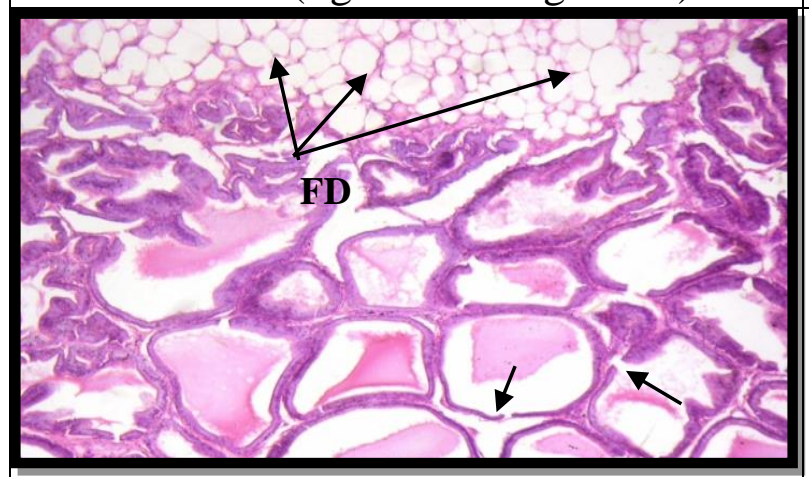

Figure (2): Photomicrograph of rat's prostate stained with (H\&E) shows epithelial disruption (A) of the acini and inflammatory cells (IC) invasion of the stoma examined at 24 hours PM (light Mic.Mag.X200).

Figure (3): Photomicrograph of rat's prostate stained with $(\mathrm{H} \& \mathrm{E})$ shows atrophy and epithelial disruption (arrow) of the acini and fatty degeneration (FD) of the stroma examined at 2 days PM (light Mic.Mag.X 200).
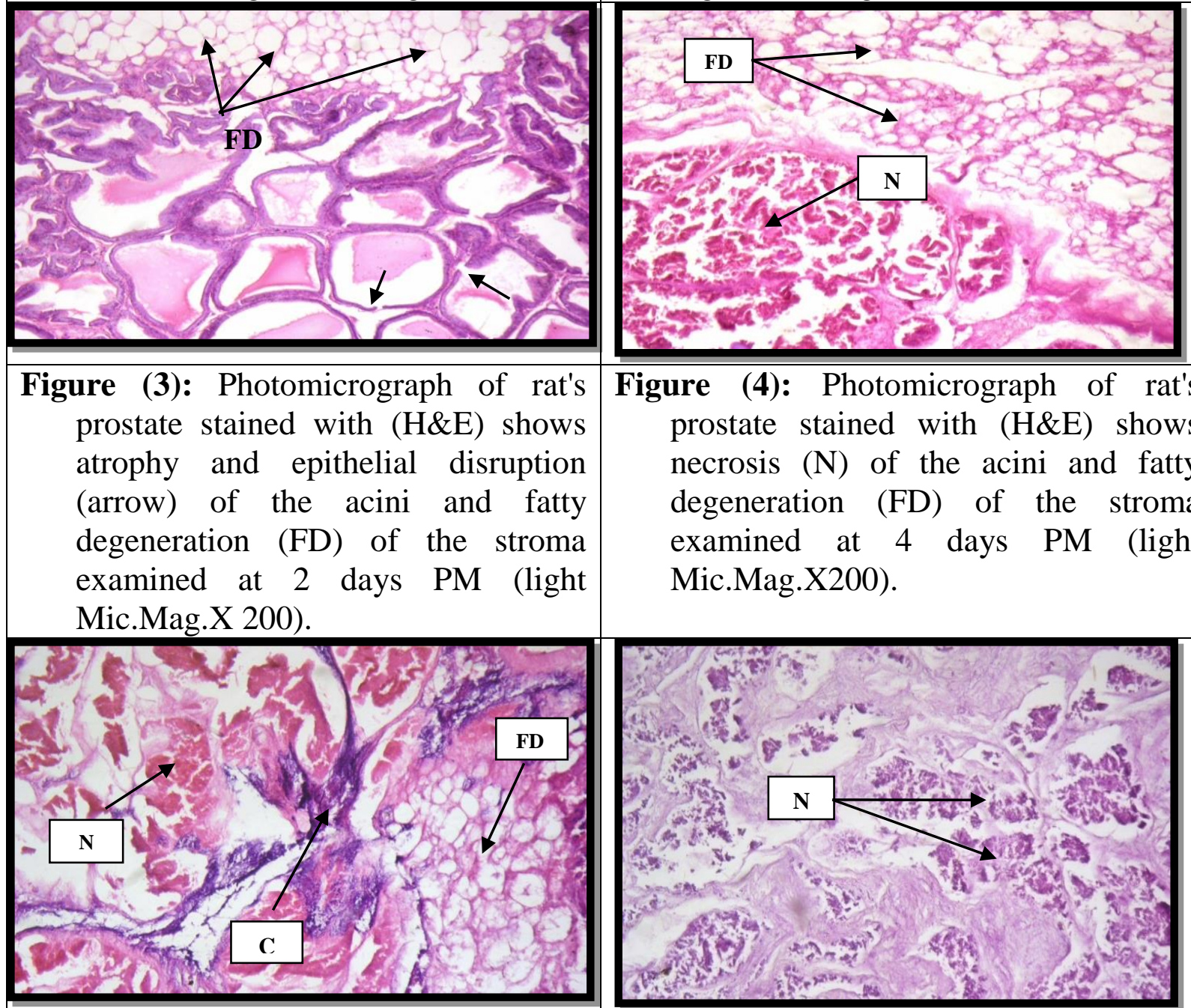

Figure (4): Photomicrograph of rat's prostate stained with (H\&E) shows necrosis $(\mathrm{N})$ of the acini and fatty degeneration (FD) of the stroma examined at 4 days PM (light Mic.Mag.X200).

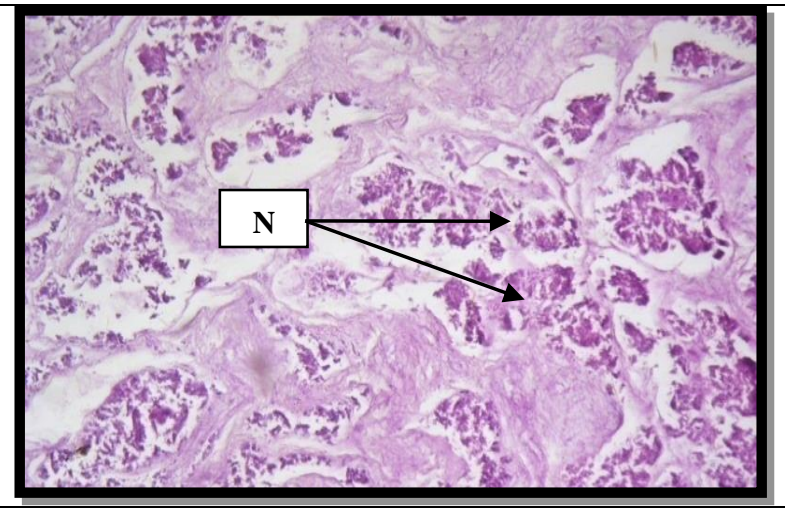

Figure (5): Photomicrograph of rat's prostate stained with $(\mathrm{H} \& \mathrm{E})$ shows necrosis $(\mathrm{N})$ of the acini, fatty degeneration (FD) and calcification (C) of the stroma examined at 6 days PM (light Mic.Mag.X200).

Figure (6): Photomicrograph of rat's prostate stained with (H\&E) shows extensive necrosis (N) of the acini examined at 1 week PM (light Mic.Mag.X100). 


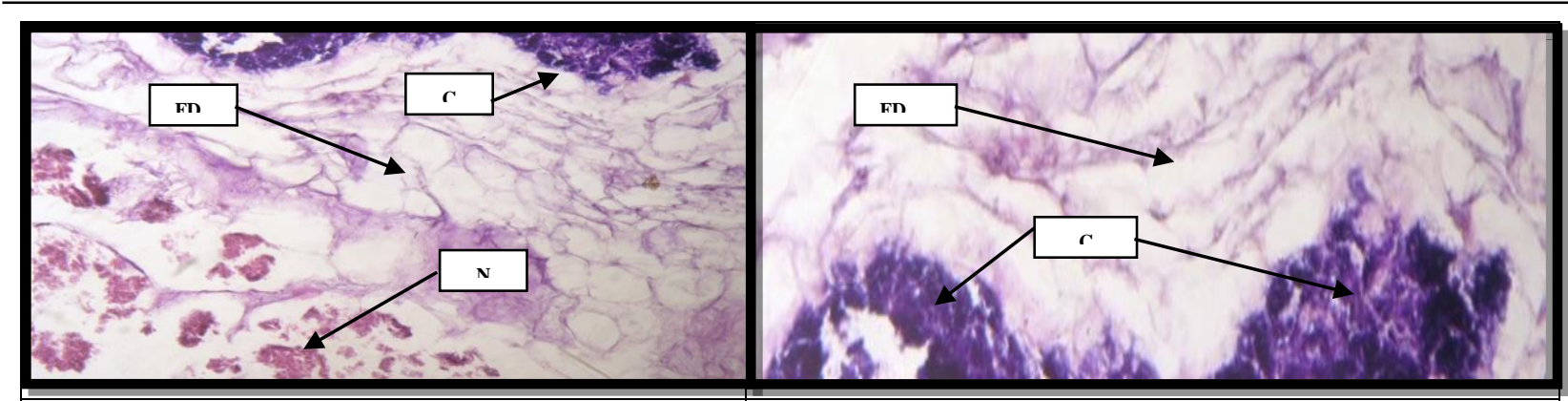

Figure (7): Photomicrograph of rat's prostate stained with (H\&E) shows necrosis (N) of the acini, fatty degeneration (FD) and calcification (C) of the stroma examined at 3 weeks PM (light Mic.Mag.X100)
Figure (8): Photomicrograph of rat's prostate stained with (H\&E) shows extensive fatty degeneration (FD) and calcification $(C)$ of the stroma. There was complete disappearance of the normal prostatic architecture examined at 4 weeks PM. (light Mic.Mag.X100)

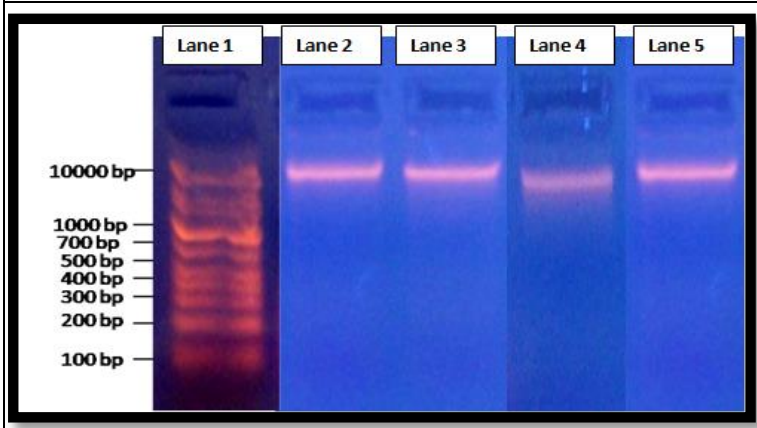

Figure (9): Photomicrograph of agarose gel electrophoresis of rat's prostate appearing as a single band near the well examined at 0 to 12 hours PM. Lane 1 is the DNA ladder.

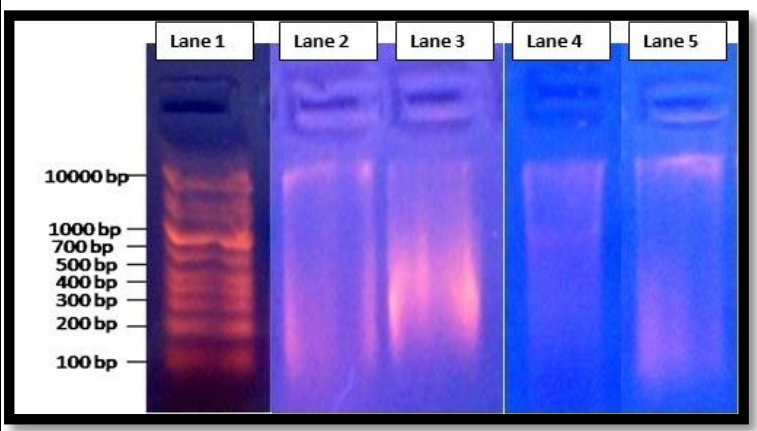

Figure (11): Photomicrograph of agarose gel electrophoresis of rat's prostate appearing as a single band near the well in addition to a homogenous smear down the lane, examined at 2 days PM. Lane 1 is the DNA ladder.

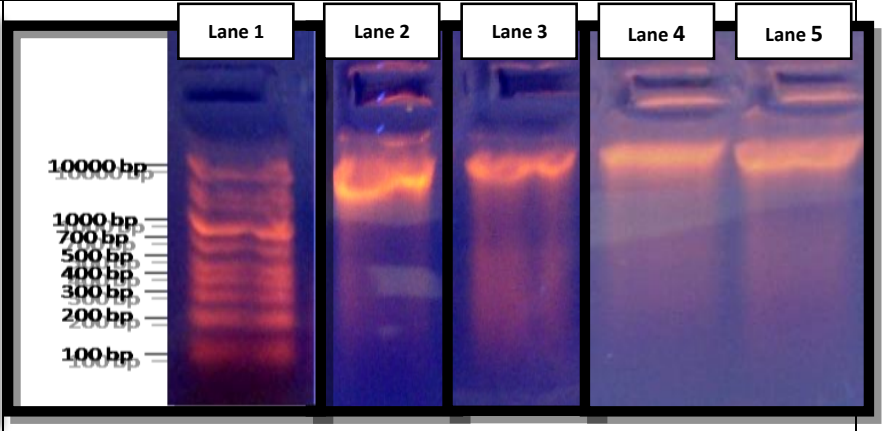

Figure (10): Photomicrograph of agarose gel electrophoresis of rat's prostate appearing as a single band near the well in addition to a homogenous smear down the lane, examined at 24 hours PM. Lane 1 is the DNA ladder.

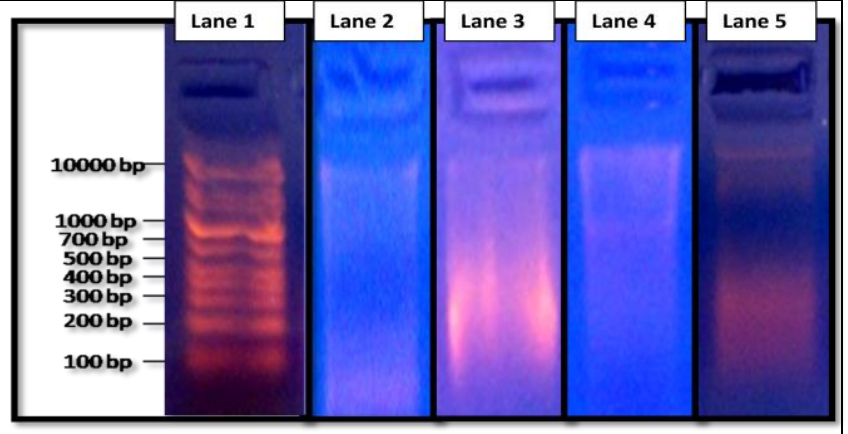

Figure (12): Photomicrograph of agarose gel electrophoresis of rat's prostate appearing as a single band near the well in addition to a homogenous smear down the lane (lane 2, 3 and 4) and degraded to DNA fragments of low molecular weight smeared down the lane to less than 400 base pair (bp) in lane 5, examined at 4 days PM. Lane 1 is the DNA ladder. 


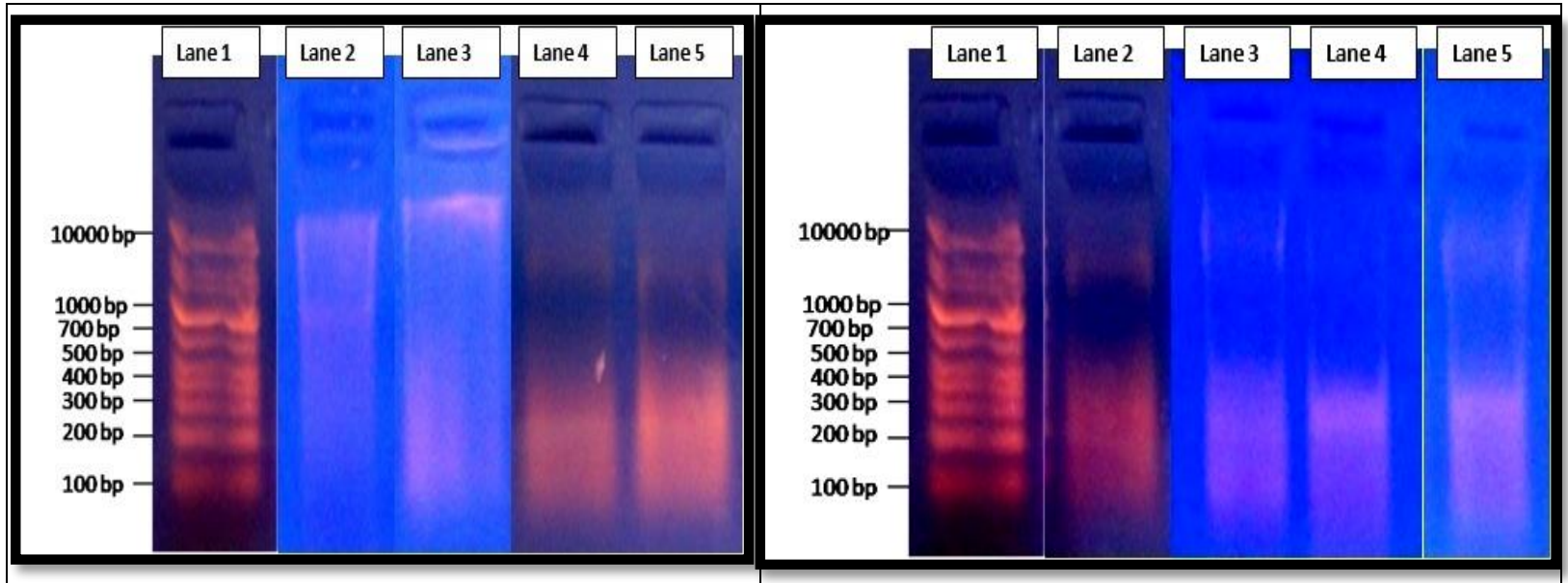

Figure (13): Photomicrograph of Figure (14): Photomicrograph of agarose agarose gel electrophoresis of rat's prostate appearing as a single band near the well in addition to a homogenous smear down the lane (lane 2 and 3) and degraded to DNA fragments of low molecular weight smeared down the lane to less than 400 base pair (bp) in lane 4 and 5 , examined at 6 days PM. Lane 1 is the DNA ladder.

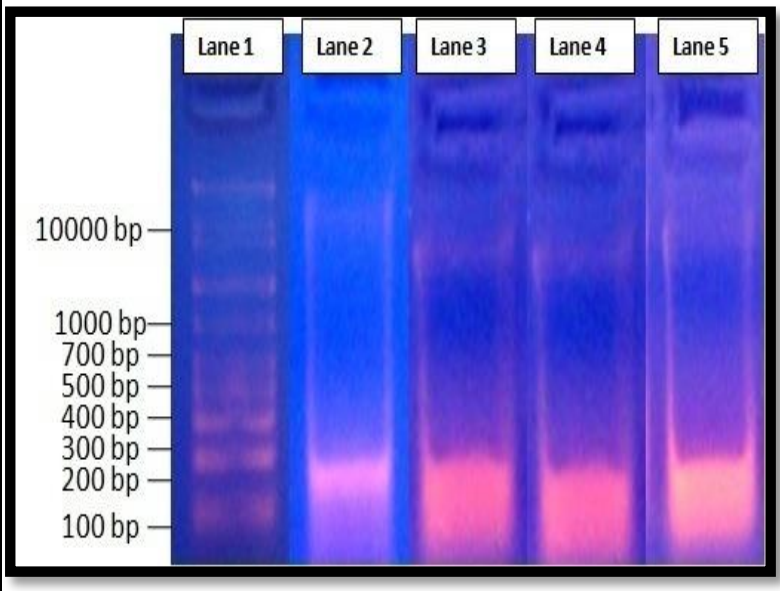

Figure (15): Photomicrograph of agarose gel electrophoresis of rat's prostate degraded to DNA fragments of low molecular weight smeared down the lane to less than 200 base pair (bp) (lane 2, 3, 4 and 5), examined at 2 weeks PM. Lane 1 is the DNA ladder. gel electrophoresis of rat's prostate degraded to DNA fragments of low molecular weight smeared down the lane to less than 400 base pair (bp) (lane 2, 3, 4 and 5), examined at 1 week PM. Lane 1 is the DNA ladder.

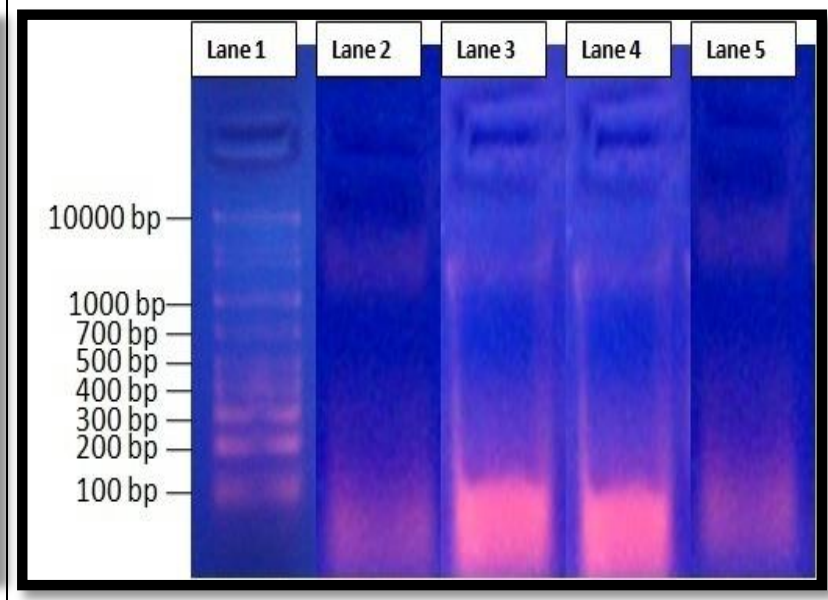

Figure (16): Photomicrograph of agarose gel electrophoresis of rat's prostate degraded to DNA fragments of low molecular weight smeared down the lane to less than 100 base pair (bp) and faint bands near the well (lane 2, 3, 4 and 5), examined at 3 weeks PM. Lane 1 is the DNA ladder. 


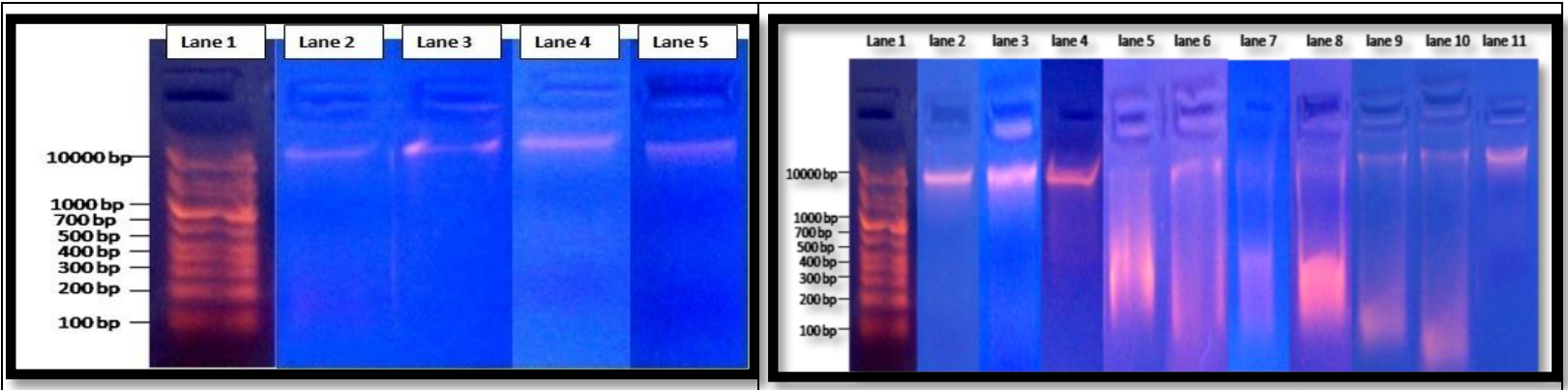

Fig.(17): Photomicrograph of agarose gel electrophoresis of rat's prostate appeared as a single band near the well in all the lanes, examined at 4 weeks PM. Lane 1 is the DNA ladder.
Fig.(18): Photomicrograph of agarose gel electrophoresis showing the effect of the progression of post-mortem interval on the DNA extracted from rats' prostate at different PMI.

Lane 1: DNA ladder Lane 2: 0 hour PM Lane 3: 12 h PM Lane 4: 24 h PM

Lane 5: 2 days Lane 6: 4 days PM

Lane 7: 6 days PM Lane 8: $1 \mathrm{w}$ PM

Lane 9: 2 w PM

Lane 10: 3 w PM

Lane 11: 4 w PM

\section{DISCUSSION}

For long decades, many methods have been proposed for estimation of PMI, even though most of these methods were relatively inaccurate (Smart and Kaliszan, 2012). After death the structure composition of the human body is severely changed due to a complicated biochemical and pathological processes. The succession of these modifications and their degree of alteration allow PMI estimation (Ferreira and Cunha, 2013).

Histopathological results of the present study revealed that, light microscopic examination of prostate samples didn't detect any structure abnormality during the first twelve hours PM. After twenty-four hours PM, significant epithelial disruption, inflammatory cells and fatty degeneration began to appear in the prostatic acini. Two days PM, the prostatic acini started to show significant atrophy and necrosis. Four days PM the previous degenerative change became more extensive. By six days PM, stromal calcification started to appear. One to four weeks PM, significant decrease in fatty degeneration was observed while, the prostatic acinar epithelial disruption, atrophic acini, necrosis and stromal calcification increased and became extensive till no more normal glandular or fibromuscular architecture of the prostatic gland can be detected.

From the previous pathological results we can deduce that, by six days PM the acinar portions as well as the fibromuscular portions of the examined glands were affected by all the detected degenerative changes except for the calcification which affects only $25 \%$ of samples. With the progression of PMI, these degenerative changes became more extensive to affect $100 \%$ of experimental animals. Two weeks PM complete disappearance of the classical histological architecture occurred, which rendered the use of histopathological examination of rat's prostate of limited value for PM interval estimation after this period. 
The results of extracted DNA from prostate gland showed that DNA resisted the degradation up to twentyfour hours PM that rendered the prostate's DNA useful in determination of PMI in the first twenty-four hours. Twenty-four hours PM, degradation patterns began, progressed and resulted into small pieces of low molecular weight DNA less than 400 bp (six days PM). By three weeks PM DNA became more degraded to reach less than 100 bp. By four weeks PM, DNA disappeared completely from the gel, followed by reappearance of new intact non fragmented DNA.

The previous results concluded that post-mortem degradation (fragmentation) of genomic DNA extracted from prostate gland was directly proportional to time progressed since death. Also, the results showed that prostatic DNA was completely degraded by 2 weeks PM, which rendered it useless in estimation of PMI after this period.

Prostatic post mortem histopathological changes are also directly proportional to time progressed since death but it is only of value for early and intermediate PMI.

These histopathological results are in controversy with Saukko and Knight (2016), who reported that prostate and uterus may still be recognizable in a partially skeletalized body for a year PM. But the rapid degradation rate of the rat prostate may be attributed to the smaller size of rats' prostate in comparison to that of human being as well as the difference in the lining epithelium of the rats' prostate which is lined by simple columnar epithelium compared to the more resistant pseudo stratified and stratified columnar epithelium lining of human prostate. This is in consistent with
(Matuszewski et al., 2014) who stated that the mass of the carcass is the most important endogenous factor that influences the rate of post mortem decomposition as well as the estimation of PMI. They demonstrated that bodies of small masses decomposed more rapidly than those with larger one.

Reviewing the literature regarding previous studies tried to investigate the possibility of using normal prostatic tissue for detection of PMI (since prostate resists autolysis and putrefactive processes) revealed that there are no previous studies in this field. Thus, this study results seem to be the first indication for the usefulness of using normal prostatic tissue in estimation of the post mortem interval. So, all histopathological changes as well as DNA degradation can be correlated to the processes of autolysis and putrefaction ending in cell death.

As a result of somatic death, all vital body functions ceased. Cells become ischemic and survive for varying periods of time, depending on their types. Anoxic post-mortem effects (ischemia, glycolysis, and proteolysis) make changes in enzyme activity and the ultra-structures of cells. Intracellular organelles degenerate according to their oxygen requirement. The rate at which post mortem autolysis occurs depends on the following factors: 1) concentration of cellular proteolytic enzymes, 2) environmental temperature, 3) ante mortem health condition, post mortem autolysis occurs rapidly in those with fever, congestive heart failure; etc. These changes can be easily detected and correlated to PMI by histopathological examination (Karadžić et al., 2010).

Reisner (2015) stated that PM cell death occurs by two alternatives, opposite modes: apoptosis which is a 
programmed, managed form of cell death and necrosis which is an unordered and accidental form of cellular death. The entire cell and its organelles (mitochondria and endoplasmic reticulum) are swollen, with increased concentrations of water, sodium, and chloride and a decreased concentration of potassium that results into irreversible injury and necrosis. Enzymes leak out of lysosomes and enter the cytoplasm leading to cellular digestion and necrosis. Cellular contents also leak out through the damaged plasma membrane and elicit inflammatory reaction. On the other hand, when the cell is deprived of growth factors, DNA and proteins are damaged beyond repair and the cell kills itself by process, called apoptosis characterized by nuclear dissolution without complete loss of membrane integrity. The apoptotic pathway is activated by release of pro-apoptotic molecules from leaky mitochondria. Finally, the dead cells are replaced by large masses composed of phospholipids and fatty acids (fatty degeneration) that may become calcified.

\section{Kroemer et al. (2010) and Jiang} et al. (2013), suggested that apoptosis may contribute to post mortem prostatic cell death through a cascade of biochemical and morphologic changes that lead to its death and elimination. After death the production of androgenic enzymes (responsible of both stimulating the proliferation as well as inhibiting the rate of the glandular epithelial cell death) is stopped, this triggers the programmed cell death pathway resulting in glandular, DNA degeneration and cellular fragmentation. So, the post mortem morphological changes could be referred to absence of androgenic enzymes after death. .

Another mechanism contributing to explain histopathological as well as DNA degradation is that; PM hypoxia leads to loss of ATP resulting into failure of many energy-dependent cellular systems, including: 1) Ion pumps (leading to cell swelling, and influx of $\mathrm{Ca}^{2+}$ ). 2) Depletion of glycogen stores, with accumulation of lactic acid, which lowers the intracellular $\mathrm{pH}$. 3) Reduction in protein synthesis and degradation result into atrophic changes. Persistent hypoxia worsens ATP depletion as well as free radical accumulation which cause cell membrane damage by crosslinking of proteins, lipid peroxidation of cellular membranes and DNA damage and degradation (Saukko and Knight, 2016).

Several PM environmental conditions like heat, light, and humidity as well as bacterial and fungal contamination lead to physical, chemical, and biochemical degradation of genomic DNA (Arismendi et al., 2004; Shved et al., 2014). These factors can be further classified into an enzymatic process or a non-enzymatic process. The enzymatic process is the first to degrade the protein structures complexed with and protecting DNA by cellular proteases. This process exposes the phosphodiester backbone of DNA to digestion by the leaked endonucleases leading to cell death. The dead cells release nutrient rich fluids that stimulate the growth of environmental microorganisms, which accelerate the decomposition of cellular material and digest DNA. As the cellular repairing systems become nonfunctioning this gives opportunity to the non-enzymatic mechanisms (hydrolytic and oxidative reactions, 
cross linking, and radiation), to contribute to DNA degradation. This process proceeds slowly to degrade DNA. Hydrolytic reactions are $\mathrm{pH}$ and temperature that cleave the glycosidic sugar base bond resulting in the loss of a base. In addition, ionization reactions release free-radical oxygen and peroxides that may modify the sugar structure (Mitchell et al., 2005; Alaeddini et al., 2010).

Gorgan et al. (2013) reported that the post mortem DNA degradation in bone fragments is due to release of nucleases that cause oxidative and hydrolytic damage to DNA after cellular rupturing. This ends by DNA fragmentation, base alteration, crosslinking, and other forms of degradation and damage. On these bases, ancient DNA fragments rarely exceed $500 \mathrm{bp}$ in length and are characterized by a high frequency of miscoding. As these fragments can be quantified they can be used as a predictor of PMI.

On gel electrophoresis, biological samples displaying DNA degradation by lysosomal proteases would produce smears throughout the gel track down the lane. This smearing is the visual result of large pieces of genomic DNA that are broken down into thousands of smaller fragments (Barril and Nates, 2012).

Osaretin et al. (2015) showed that DNA fragmentation is a reduction of high molecular weight DNA and an increase of smaller size DNA fragments. These fragments can be seen on the agarose gel as vertical bands known as smearing.

Malone (2017) attributed the appearance of smearing on gel electrophoresis to several factors: 1) improperly prepared gel, which if not poured correctly will not polymerized or solidify evenly, thus causing the molecules to smear. 2) Too much DNA was loaded on the gel resulting in trailing and smearing. 3) Molecules break down either artificially using enzymes or naturally by environmental factors. 4) Contamination of DNA sample with a protein.

Many studies attributed the occurrence of apoptosis to activation a specific nuclease called caspaseactivated DNase (CAD) that, leads to cleavage of DNA at inter-nucleosomal linker sites, generating fragments of 200 base pairs known as DNA ladders. These ladders were detected classically by agarose gel (Krysko et al., 2008; Saadat et al., 2015).

Gomaa et al. (2013) perceived different patterns of DNA degradation on agarose gel. They related the rate of DNA fragmentation to the progression of PMI. The more degraded fragments are the smaller that migrate faster through the gel. The Larger molecules migrate more slowly because they become entangled in the gel matrix.

At late post mortem period (three weeks PM) of the present study, DNA disappeared from the gel, displayed as complete disappearance of the genomic band. This pattern may be due to further progression of the fragmentation process which can be explained by the rupture of cell membranes during later stages of cell death leading to the release of nutrient-rich fluids, which encourage the growth of environmental microorganisms that contain nuclease enzymes able to further decomposition of nucleic acids and most of their degradation products (Alaeddini et al., 2010).

Complete disappearance of DNA fragments as well as DNA bands may be attributed to several technical factors; low DNA concentration or insufficient quantity loaded on the gel, 
puncturing the well while loading the DNA, DNA is not present and no band will exist. Also prolonged electrophoresis may cause diffusion of smaller DNA fragments in the gel. Long exposure of DNA to UV fluorescence could degrade nucleic acids and thus, the sharpness of the bands would be negatively affected .Extensive DNA degradation which accelerates the minute fragments to run off the end of the gel prior to visualization (Reddy and Raju, 2012).

With the progression of PMI (3 to 4 weeks); the DNA reappeared as an intact band near the well. This could indicate the commencement of so extensive sample damage. During the putrefaction process; DNA samples could contain both the examined DNA and a bacterial, fungal or any other DNA which invade the samples post mortem This was supported by (Tan, 2011; Malone, 2017) who stated that forensic samples have the potential to be contaminated with non-human mammalian protein, bacterial or fungal DNA which, when present, contributes to reappearance of DNA in the sample.

The current results detected also variation in intensity of the bands, which can be related to quantity or concentration of DNA loaded on the gel. Darker bands have more DNA while faint or no band have insufficient quantity or concentration of DNA. As small fragments do not have as many bases available for intercalation with ethidium bromide dye as the larger ones, they also travel faster. Consequently, they appeared on the gel faint in intensity and farther in position (Barril and Nates, 2012).

\section{CONCLUSIONS \& RECOMMENDATIONS:}

According to the results of this study, it can be concluded that there is a direct relationship between the progress of PMI and the prostatic PM histopathological changes as well as its DNA degradation. These changes revealed successive time dependent process that can be used as a predictor for PMI estimation. The slower degradation of prostate DNA makes it a preferable tool for forensic studies at later PMI than its histopathological examination.

Although prostate is an organ that resists putrefaction for a relatively long period of time, scientific researches in the field of using post mortem morphological changes of prostate in determining PMI are lacking in the literature. It is recommended that further researches should be done to find out any significant value of prostatic morphological changes in estimation of time death. Great progress has been developed in methods of extractions and detections of DNA. So, it is recommended that further researches should be done to compare different DNA extraction techniques as well as different DNA analytical methods to determine the best extraction technique and the better analytical method that should be applied in routine forensic investigation of suspected criminal cases to determine time passed since death.

\section{REFERENCES}

Agresti, A. (2007): Chi-Squared Tests of Independence. In: An Introduction to Categorical Data Analysis, (2 ${ }^{\text {nd }}$ Ed.). Florida USA: Willey-Interscience. A John Wiley and Sons, Inc., Publication. Section 2.4.1. pp: 35 . 
Alaeddini, R.; Walsh, S.J. and Abbas, A. (2010): Forensic Implications of Genetic Analysis from Degraded DNA - A Review. Forensic Science International, 4:148-157.

American Veterinary Medical Association (AVMA) (2013): Guidelines for the Euthanasia of Animal. ISBN 978-1-882691-21-0.

Arismendi, J.L.; Baker, L.E. and Matteson, K.J. (2004): Effects of Processing Techniques on the Forensic DNA Analysis of Human Skeletal Remains. Journal of Forensic Sciences, 49(5):1-5.

Barril, P. and Nates, S. (2012): Introduction to Agarose and Polyacrylamide Gel Electrophoresis Matrices with Respect to Their Detection Sensitivities. In Gel Electrophoresis - Principles and Basics ( $1^{\text {st }}$ ed.), Magdeldin, S. ed. Croatia: Published In Tech Rijeka. Ch. 1. pp: 1-13.

Chandrakanth, H.V. ; Kanchan, T. ; Balaraj, B.M. ; et al. (2013): Postmortem vitreous chemistry-An evaluation of sodium, potassium and chloride levels in estimation of time since death (during the first 36 $\mathrm{h}$ after death). Journal of Forensic and Legal Medicine, 20(4): 211216.

DNeasy ${ }^{\circledR}$ Blood \& Tissue Handbook, Qiagen, (2011): DNeasy ${ }^{\circledR}$ Blood \& Tissue Handbook, Qiagen Quik Start protocol.www.qiagen.com/ handbooks. (Last assessed December 2017).

Elias, E.; Osman, K. ; Abdul aziz, S. ; et al. (2004): Determination of Time of Death Based on Basic Histological Stain and Immunostain Changes. Jurnal Sains Kesihatan Malaysia, 2(2):63-70.
Elkins, K.M. (2013) (b):Determination of DNA Quality and Quantity Using UV-Vis Spectroscopy. In: Forensic DNA Biology . Oxford, USA: Elsevier Inc.Ch 6. pp: 59-62.

Elkins, K.M.(2013) (a): Determination of Quality and Quantity of DNA Using Agarose Gel Electrophoresis. In: Forensic DNA Biology. Oxford, USA: Elsevier Inc.Ch 5. pp: 53-57.

Ferreira, M.T. and Cunha, E. (2013): Can we infer post mortem interval on the basis of decomposition rate? A case from a Portuguese cemetery. Forensic Science International, 226(10): 288-298.

Gomaa, M.S.; Abd El-Khalek, A.M. and Sameer, M.M. (2013): The relationship between the post mortem interval and the DNA degradation in brain and liver of adult albino rats. Journal of American Science, 9(5):535-540.

Gorgan, L.; Druică, R.; Ştefan, A.; et al. (2013): Comparative DNA Degradation in Bones Fragments. International Journal of Criminal Investigation, 3 (1): 33-43.

Jiang, H. ; Sun, J. ; Xu, Q. ; et al. (2013): Marchantin $M$ : a novel inhibitor of proteasome induces autophagic cell death in prostate cancer cells. Cell Death and Disease, 4:761-766.

Karadžić, R. ; Ilić, G. ; Antović, A. ; et al. (2010): Autolytic ultrastructural changes in rat and human hepatocytes. Rom. J. Leg. Med, 18:247 - 252.

Koolhaas, J.M. (2010): The UFAW Handbook on the Care and Management of Laboratory and Other Research Animals, ( $8^{\text {th }}$ ed), Kirkood, J. and Hubrecht, R. eds. Wiley-Blackwell. Ch 22. pp: 311326. 
Kroemer, G.; Marino, G. and Levine, B. (2010): Autophagy and the integrated stress response. Mol. Cell, 40:280-293.

Krysko, D.V.; Berghe, T.V.; D'Herde, K.; et al. (2008): Apoptosis and necrosis: detection, discrimination and phagocytosis. Methods, 44(3):205-221.

Malone, M. (2017): What Causes Smearing in Electrophoresis? https://sciencing.com/causessmearing-electrophoresis6404726.html.(Last accessed January 2018).

Matuszewski, S.; Konwerski, S. and Fratczak, K. (2014): Effect of body mass and clothing on decomposition of pig carcasses. Int. J. Legal Med., 128(6):1039-48.

Mitchell, D.; Willerslev, E. and Hansen, A. (2005): Damage and repair of ancient DNA. Mutation Research, 571:265-76.

Osaretin, A.T.; Motolani, A. ; Ayooluwa, B. ; et al. (2015): Post mortem Time Affects Brain, Liver, Kidney and Heart DNA in Male Rat. American Journal of Biochemistry, 5(1): 1-5.

Reddy, P.R. and Raju, N. (2012): Gel-Electrophoresis and Its Applications. In Gel Electrophoresis - Principles and Basics, (1 ${ }^{\text {sted}), ~ M a g d e l d i n, ~ S . ~ e d ., ~}$ Croatia: Published In Tech Rijeka .pp:16-28.

Reisner, M.H. (2015): Cell Injury, Cell Death, and Aging .In: Pathology: A Modern Case Study, China: McGraw-Hill Education. Ch 2.

Saadat, Y.R. ; Saeidi, N. ; Vahed, S.Z. ; et al. (2015): An update to DNA ladder assay for apoptosis detection. Bioimpacts. 5(1): 25-28.

Saukko, P. and Knight, B. (2016): Pathophysiology of death. In:
Forensic pathology, $\left(4^{\text {th }} \mathrm{ed}\right)$, Boca Raton, Florida: CRC press Taylor and Francis group. Ch 2. pp: 54-95.

Shved, $\quad$ N.; Haas, C. ; Papageorgopoulou, C. ; et al. (2014): Post Mortem DNA Degradation of Human Tissue Experimentally Mummified in Salt. PLOS ONE 9(10): e110753.http://dx.doi.org/10.1371 /journal.pone.0110753. (Last accessed February 2017).

Smart, J.L. and Kaliszan, M. (2012): The post mortem temperature plateau and its role in the estimation of time of death: a review. Legal Medicine, 14(2):5562.

Szatkowski, M. ; Mycielska, M. ; Knowles, R.; et al. (2000): Electrophysiological recordings from the rat prostate gland in vitro: identified single-cell and transepithelial (lumen) potentials. B.J.U. International, 86:1068-1075.

Tan, E. (2011): Rapid Microfluidic Human Specific DNA Quantitation Final Report. Net. Bio. Available at:

https://www.ncjrs.gov/pdffiles1/n ij/grants/236825.pdf. (Last accessed February 2017).

Voytas, D. (2001): Agarose Gel Electrophoresis. In Current Protocols in Molecular Biology, Copright 2001, Ausubel, F.M. ed., Florida: Published by John Wiley and Sons, Inc. Ch 2, unit: 2.5A.12.5A.9. 


\section{الفحص الجزيئى مقابل الهستوباثولوجى العبلى الغدة البروستاتا فى تقدير فترة

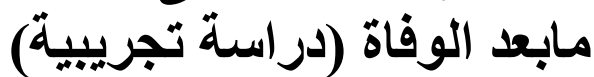

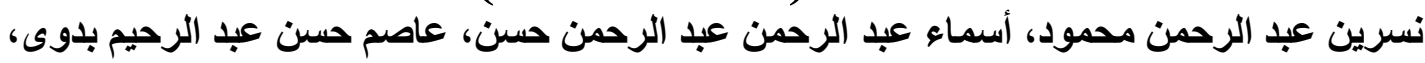

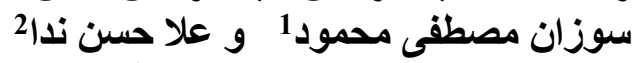

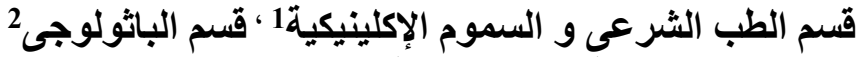

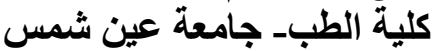

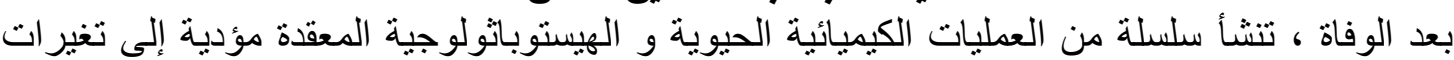
و اضحة فى تركيب و مكونات الجسم البشرى. ويحدث العديد من هذه التغير ات بطريقة متتابعة مما يُمكن من تقدير فترة ما بعد الوفاة. و نظر الكون البروستاتا أكثر الأعضاء مقاومة للتحلل ، فإن تغير اتها الخلوية الهيستو باتثولوجية

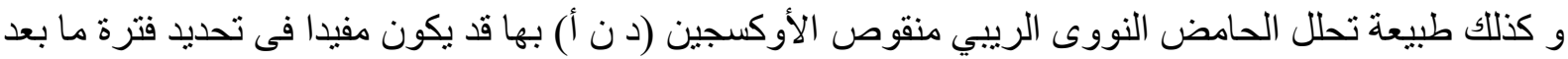

و تهدف هذه الاراسة إلى تقدير فترة ما بعد الوفاة عن طريق الإختبار الهيستوباثولوجي للبروستاتا الوفاة.

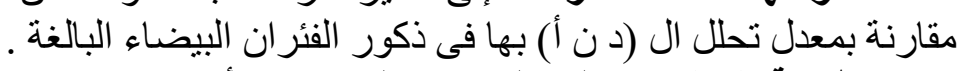

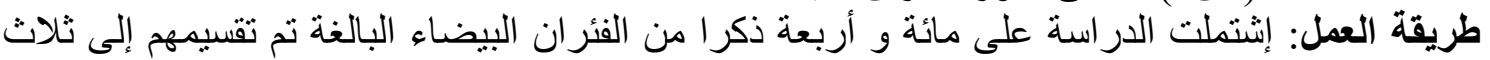

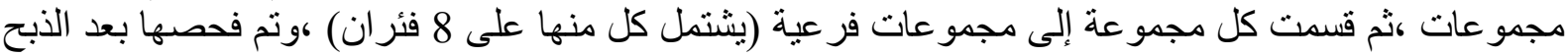

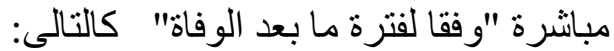

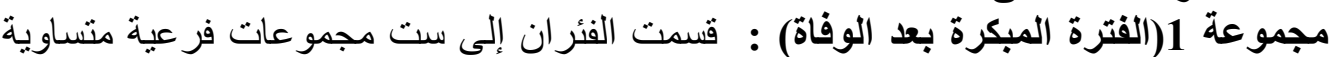

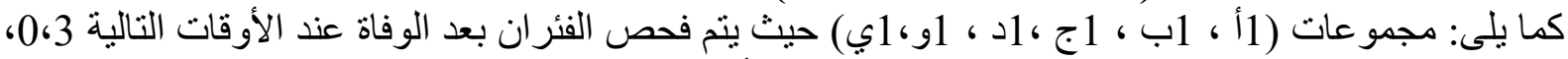

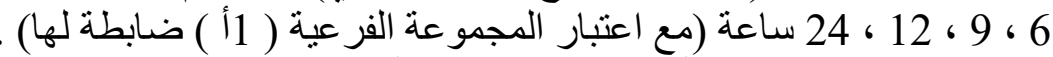

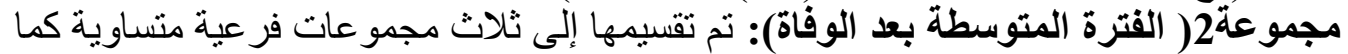

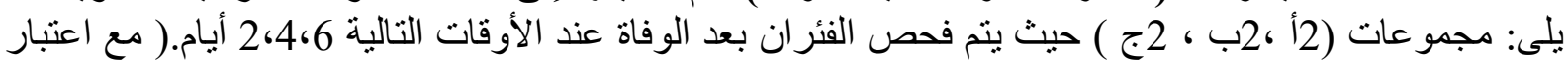

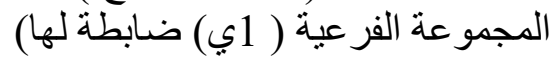

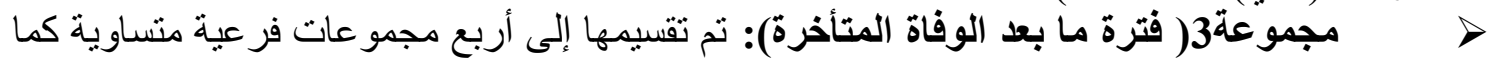

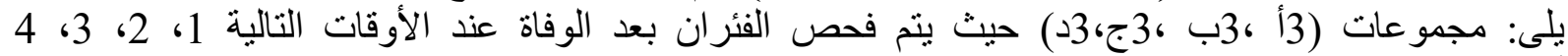

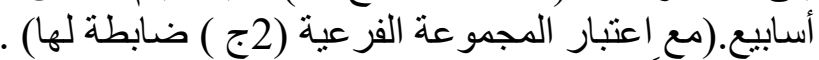

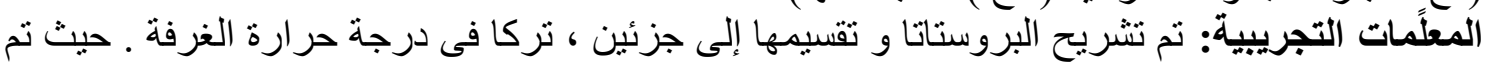

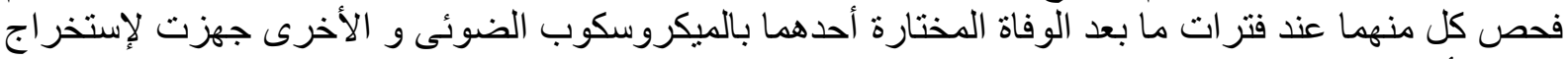
ال(د ن أ) بو اسطة تحليل الهجرة الكهربائية.

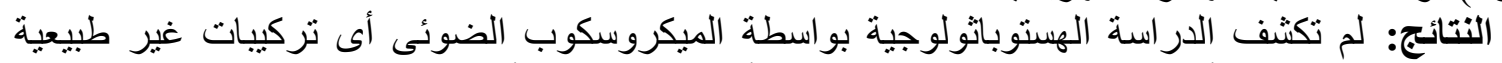

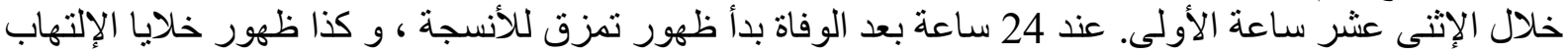

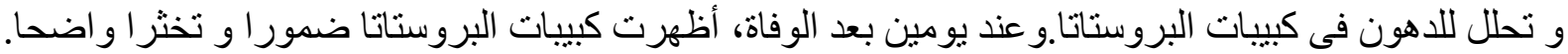

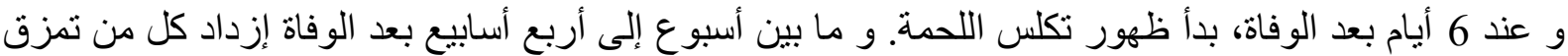

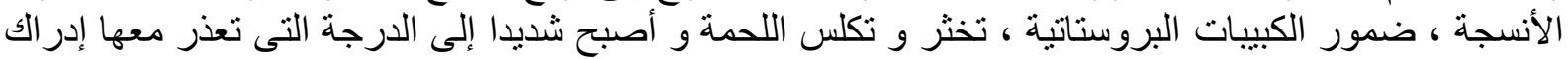
التركيب الطبيعى للغدة و كذللك تكوينها العضلى التئى الليفى.

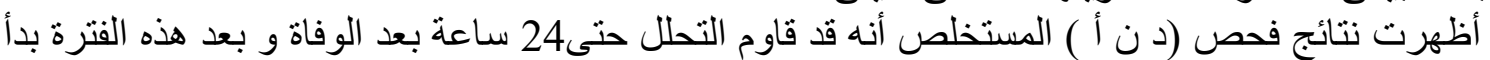

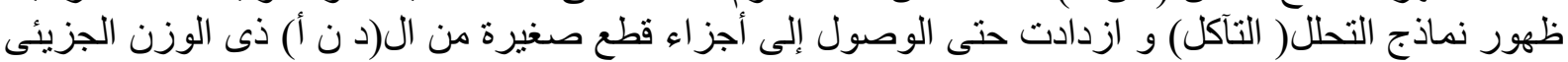

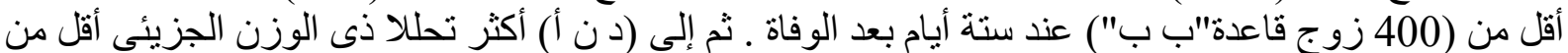

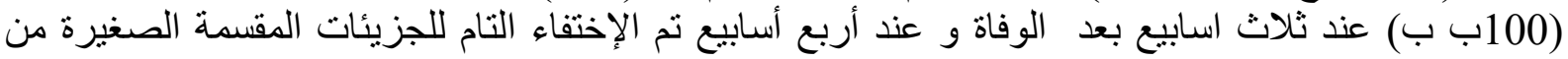

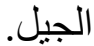

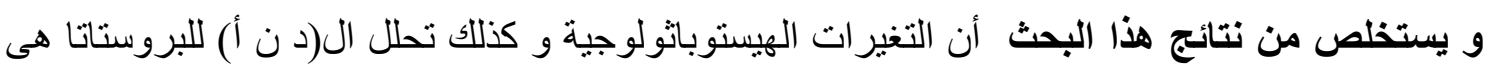

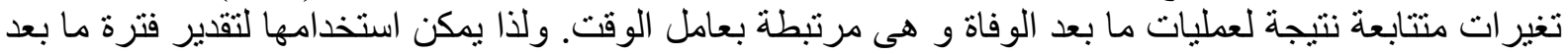

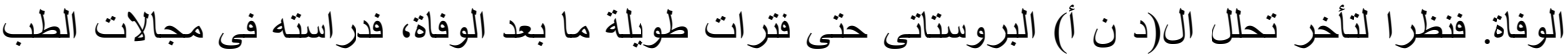

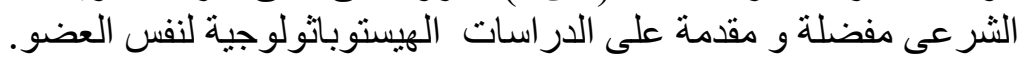

